\title{
Effect of DEM data resolution on low relief region sub-watershed boundaries delineating using of SWAT model and DEM derived from CARTOSAT-1 (IRS-P5), SRTM and ASTER
}

\author{
Kishan Singh Rawat ${ }^{1 *}$, Gopal Krishna², Amresh Mishra ${ }^{2}$, Jitendra Singh ${ }^{2}$ and Shashi \\ Vind Mishra ${ }^{3}$ \\ ${ }^{1}$ Water Technology Centre, Indian Agricultural Research Institute, New Delhi-110012, INDIA \\ ${ }^{2}$ Division of Agricultural Physics, Indian Agricultural Research Institute, New Delhi-110012, INDIA \\ ${ }^{3}$ Division of Environment, Indian Agricultural Research Institute, New Delhi-110012, INDIA \\ *Corresponding author. E-mail: ksr.kishan@gmail.com
}

Received: January 29, 2014; Revised received: April 12, 2014; Accepted: April 20, 2014

\begin{abstract}
Watersheds are natural integrators of hydrological, biological, and geological processes and as such require an integrated approach to data analysis and modeling, which usually starts delineating accurately a polygon vector layer of watershed boundaries as input. In that way, Garrah sub-watershed in Shahjahanpur district of U.P., India, had been isolated with the objective of evaluate the accuracy of sub-watershed boundaries derived from three different sources: One was delineated by $2.6 \mathrm{~m}$ resolution CARTOSAT-1 DEM (IRS-P5) and other two were derived from a $30 \mathrm{~m}$ ASTER DEM and a $90 \mathrm{~m}$ SRTM DEM, using the Soil and Water Assessment Tool (SWAT) model. In this analysis we found that the accuracy of CARTOSAT-1 DEM is so best for accurate delineation of a sub -watershed in the management of the watershed, and the coarse spatial resolution SRTM DEM (90 m) performed much better and significantly than the high spatial resolution ASTER DEM $(30 \mathrm{~m})$ it's cause of the errors in the ASTER DEM, map algebra was used to define where the "Fill" tool had filled the sinks finding that the errors in the stream network occurred where some especially large fills had occurred. Not only the visual interpretation of the produces figures indicate the SRTM DEM delineated sub-watershed as relatively more accurate from ASTER DEM delineated sub-watershed boundaries, also statistics for the SRTM DEM elevation turned in significantly higher than that of the ASTER DEM. Overall SRTM DEMs offer more precise elevations while, ASTER DEMs offer more details. Therefore, the accuracy of the sub-watershed delineation depends on the first place on the accuracy of the DEM.
\end{abstract}

Keywords: ASTER, CARTOSAT-1, DEM, GIS, SRTM and SWAT

\section{INTRODUCTION}

Watershed-based natural resource management in plains regions is gaining interest and acceptance with government and community organizations (Estrada and Posner, 2000). Hydrological research in watersheds of developing countries is a relatively new field, therefore, hydrologic and erosion data are necessary for the development of mathematical watershed models that can simulate and evaluate existing and proposed management scenarios.

Delineation of a sub-watershed plays a vital role in the management of watershed as it forms a nucleus around which the efforts like land use, land change, soil types, geology and river flows are analyzed and conclusions are drawn by the management. The field data are collected rapidly and are processed promptly with the help of remote sensing and graphic information system technologies.

The use of Digital Elevation Models (DEMs) for the purposes of automated sub-watershed and stream delineation has increased dramatically in recent years (Marks et al., 1984; Maidment, 1999). The traditional manual methods of sub-watershed delineation are now rapidly being replaced by automated approaches with the advancements in software algorithms for quick and efficient processing. This gives advantages like reliability, reproducibility, cost saving, results within the context of digital domain which can easily be linked to other meaningful data sets for the watershed under study, over the traditional approaches (Baker and Weller, 2006). The aim of the study was to determine whether the use of SWAT software technologies with remotely sensed data regressed with a digital elevation model could produce results that are comparable to the area that has undergone significant delineation.

A sub-watershed: The area which contributes all the water to a particular stream cross-section of topography is defined as the watershed. (Jenson and Domingue, 1988; Rawat et al., 2013). The flow pathway, rates of movement, magnitude and quality of stream flow is controlled by the characteristics like climate, geology, soils, topography, land use and land cover within the watershed as the processes that determine the behavior of water in the land phase of the hydrological cycle, operates at the watershed level. A sub-watershed is a smaller watershed within 


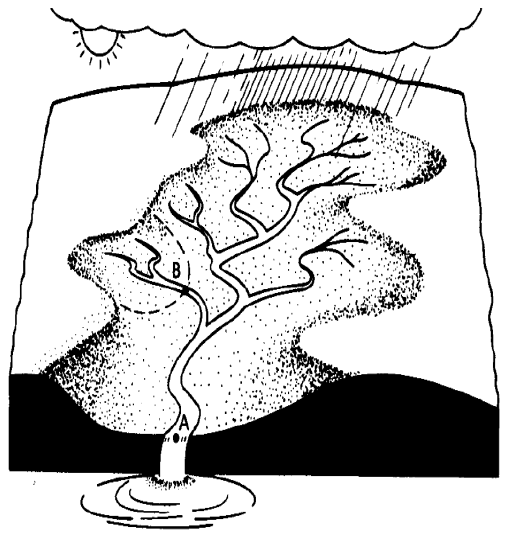

Fig.1. Ideal sub-watershed with micro sub-watershed (B) and outlet point (A).

watershed which holds the properties of a watershed. An ideal sub-watershed can be understood by fig. 1 .

Digital elevation Data: Digital elevation models (DEMs) provide good terrain representations and are commonly used in watershed modeling. These have been generated throughout the world with the development of Geographic Information Systems (GISs). These are used to derive the flow networks and can automatically generate the watershed boundaries for given outlet point with GIS technologies. Hence, hydrologically DEM of the land area of interest is an essential component to watershed delineation. CARTOSAT-1, SRTM and ASTER are the three types of DEMs used in the current study.
CARTOSAT-1(IRS-P5): The Indian Space Research Organization (ISRO) launched the Cartosat-1 satellite on May 05, 2005. The satellite was primarily designed for topographic mapping and has two panchromatic Charge Coupled Device (CCD) sensors, both with a spatial resolution of $2.6 \mathrm{~m}$. i) the Fore camera, pointing +26 degrees with respect to the nadir, and ii) the Aft camera, pointing -5 degrees with respect to the nadir. These sensors can either acquire along-track stereo images with a $27.5 \mathrm{~km}$ swath and a base to height ratio $(\mathrm{B} / \mathrm{H})$ of 0.6 or mono images with a combined swath of $55 \mathrm{~km}$.

Shuttle Radar Topography Mission (SRTM): Raw radar echoes are easily available in several resolutions of 1 arc second for US and 3 arc seconds for the world which were used to develop SRTM datasets into DEMs. The SRTM is projected into a geographic coordinate system (GCS) with the WGS84 horizontal datum and the EGM96 vertical datum.

"Research" and "Finished" grade SRTM data are available in NASA and National Geography Agency (NGA) respectively. 1 and 3 arc-seconds spatial resolutions were used to produce DEMs. These are available on internet as well. These datasets were described as high quality DEM (Rabus et al., 2003) besides the fact that problems like voids and unexpected negative values were found in its processing (Luedeling et al., 2007; Grohmann, 2006).

Advanced spaceborne thermal emission and reflection radiometer (ASTER): An advanced

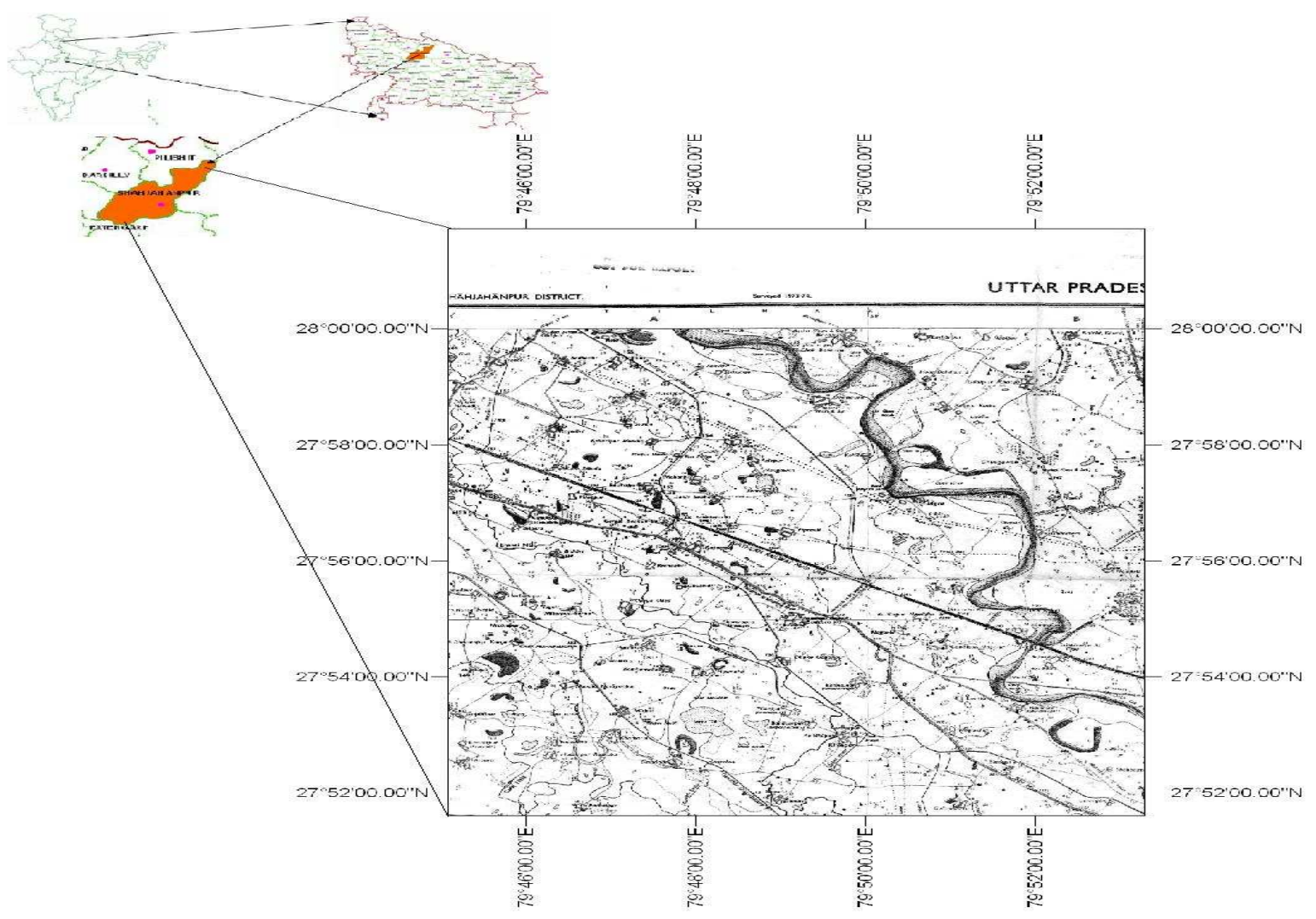

Fig. 2. Location and physiographical map of the study area. 


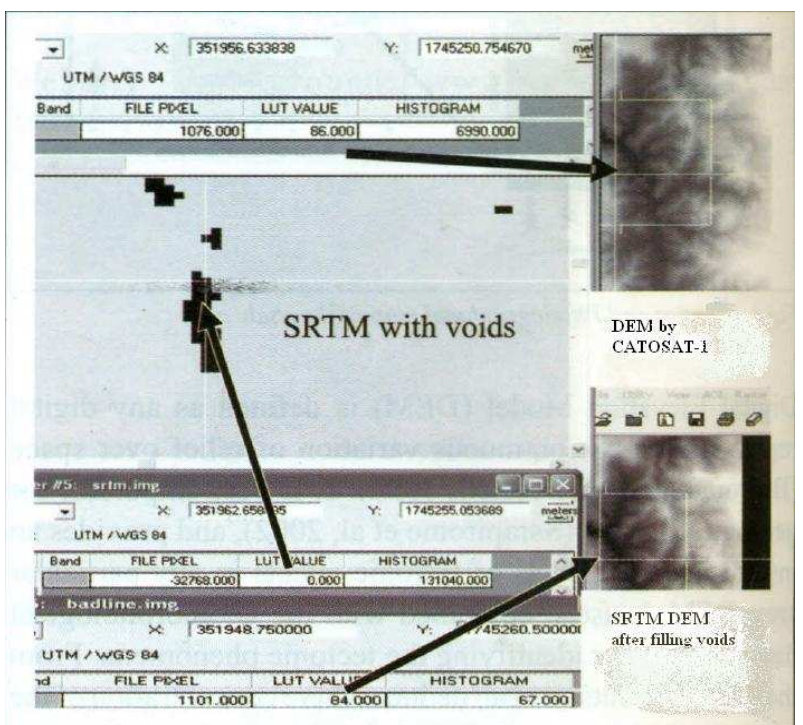

Fig.3. SRTM DEM filling voids in ENVI atmosphere.

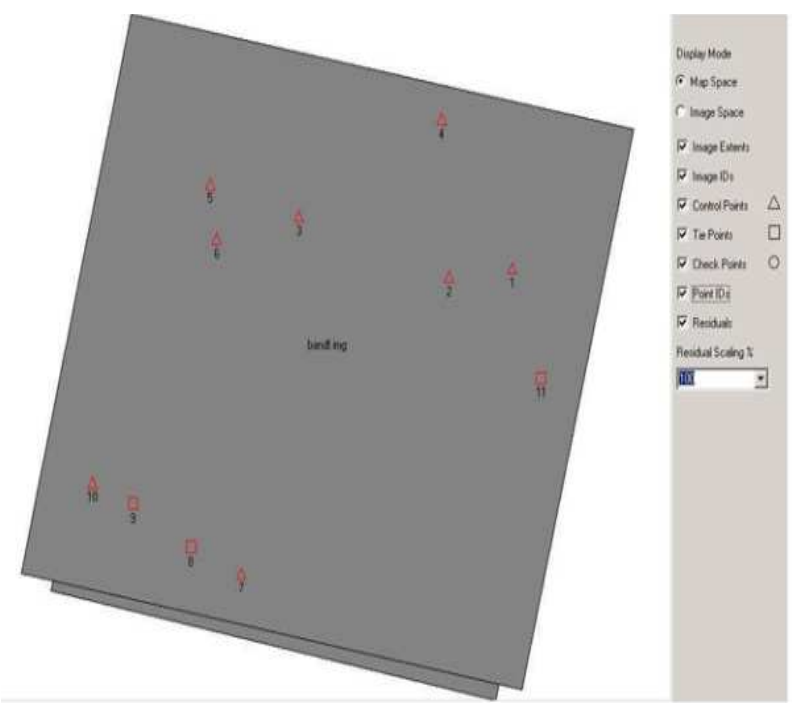

Fig. 4. Ground control points and tie points' location on the stereo model.

multi-spectral imager called Advanced Spaceborne Thermal Emission and Reflection Radiometer (ASTER) was launched on board NASA's Terra spacecraft in December, 1999 which covers wide visible to thermal infrared spectral region with 14 bands of high spatial, spectral and radiometric. Based on the wavelength, the spatial resolution can be categorised into 3groups: VNIR (visible and near-infrared) - 15 meter, SWIR (short wave infrared) - 30 meter, TIR (thermal infrared) - 90 meter.

Study area: Garrah sub-watershed (study area) in District Shahjahanpur is situated in southeast of Rohilkhand Division. Geographically, it is situated at $27.35^{\circ} \mathrm{N}$ Latitude and $79.37^{\circ} \mathrm{E}$ longitude (Fig. 2). The Geographical area of Shahjahanpur is $4575 \mathrm{Km}^{2}$ and Garrah sub-watershed area $0.043802 \mathrm{Km}^{2}$. Agriculture and agriculture based allied activities are play main role in Garrah sub-watershed. Ramganga, Garrah and Gomti are the main rivers flowing through the district Kathana, Jhukma and Mensiare are the tributaries of

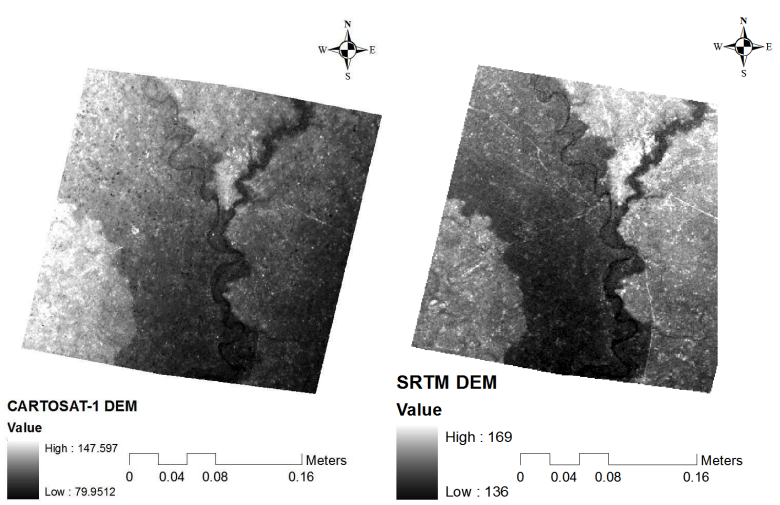

Fig. 5. CARTOSAT-1 DEM. Fig. 6. SRTM DEM.

Gomti river. Khannaut, Suketa and Kai are the tributaries of Garrah river. Jalalabad Tehsil is mostly affected by flood during monsoon season.

Topography: The major part of the Garrah sub-watershed resembles the upland plains of the Ganga valley. The continuity of plains is interrupted only by valleys predominated by numerous streams and water courses. All small and medium sized rivers flow in a South Easterly direction, indicating the general slope of the district. It is not easy to determine the exact extent of this slope from the recorded heights, although there are fairly large number of permanent station of the survey of India department (datums), but they are usually placed on places of eminences; well above the surrounding tracks. Thus the pillar at Kusrak is $184.71 \mathrm{~m}$ above mean sea level (MSL) at its base whereas, the bench mark at Katra, less than $3 \mathrm{~km}$ distant is only about $158.80 \mathrm{~m}$ MSL. Other stations are Sultanpur $(177.08 \mathrm{~m})$ Piparia $(174.35 \mathrm{~m})$, in the north of tehsil Powaywn; Karai $(170.38 \mathrm{~m})$ near Khutar; Dhaka (151.49 m) near Jalalabad and Goendi, (150.26 m) in the South-West corner. The maximum height of the ground level is approximately $166.11 \mathrm{~m}$ on the North-West border, not far from Khudaganj.

\section{MATERIALS AND METHODS}

In this study, DEM was generated from CARTOSAT1, ASTER and from SRTM data. Most of the SRTM data contains voids (cells with no elevation value) (Hall et al., 2005; Luedeling et al., 2007), thus appearing as black colour on the DEM image (Fig. 3).

These voids occur in various regions: water surface, area where the surface materials are in very law reflectance. They also occur in areas with very rough slopes. The voids have therefore, limited the utilization of the DEM generated from SRTM.

\section{Remote sensing-derived DEM dataset used}

Dataset from CARTOSAT-1: CARTOSAT-1 is a global mission. The normal life of the mission is planned to be five years. CARTOSAT-1 data for Fore and Aft scenes of west part of Shahjahanpur district, dated $2^{\text {nd }}$ October 2008 were used.

Dataset from SRTM: The free ware SRTM data was obtained from http://srtm.usgs.gov/ and ftp:// 


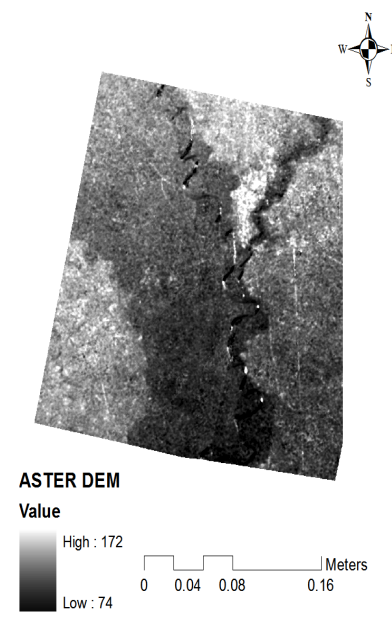

Fig.7. ASTER DEM.

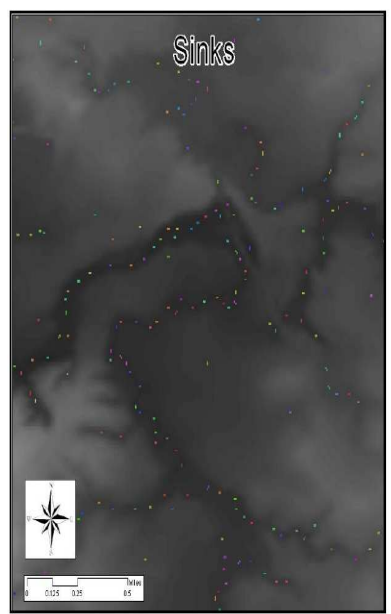

Fig.8. Sinks over SRTM DEM Data Set.

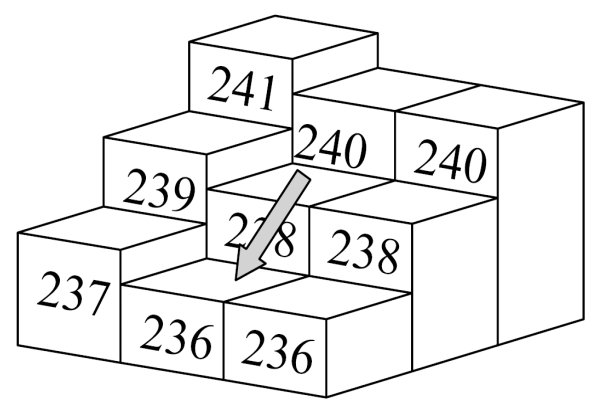

Fig. 9. Theoretical eight-cell neighborhood (numbers indicate elevation of) cell .

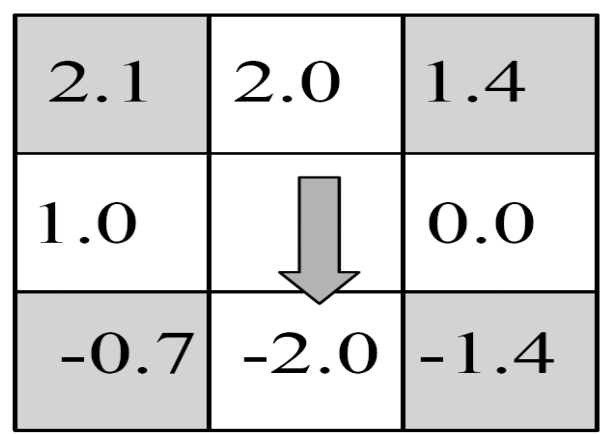

Fig.10. Computed slopes between center cell and each of the surrounding eight cells. Water follows the largest negative (downward) slope to the south.
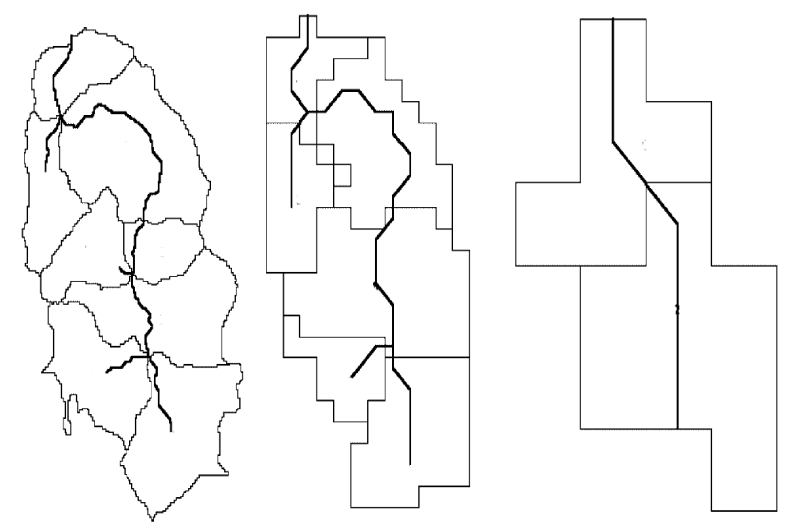

Fig. 11. SWAT watershed delineation shown at $2.6 \mathrm{~m}, 30 \mathrm{~m}$

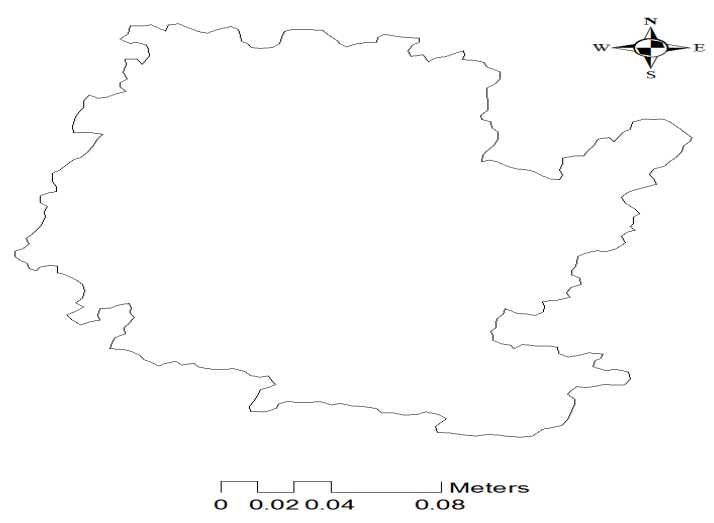

Fig. 12. Map of Garra sub-watershed, CARTOSAT-1 DEM dependent boundary.
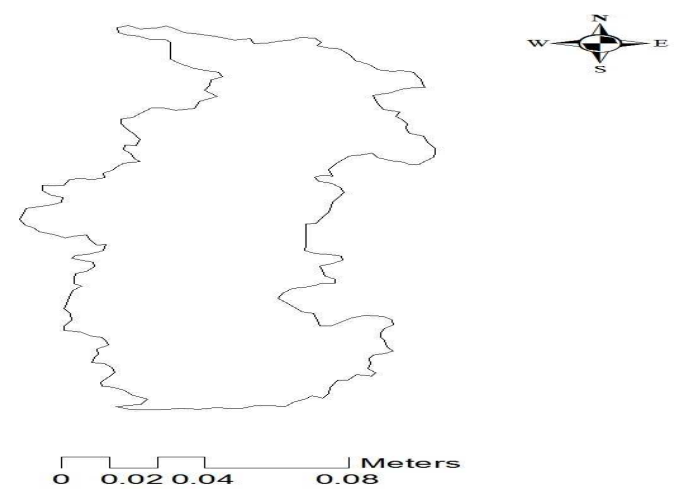

Fig. 13. Map of Garra sub-watershed, ASTER DEM dependent boundary.

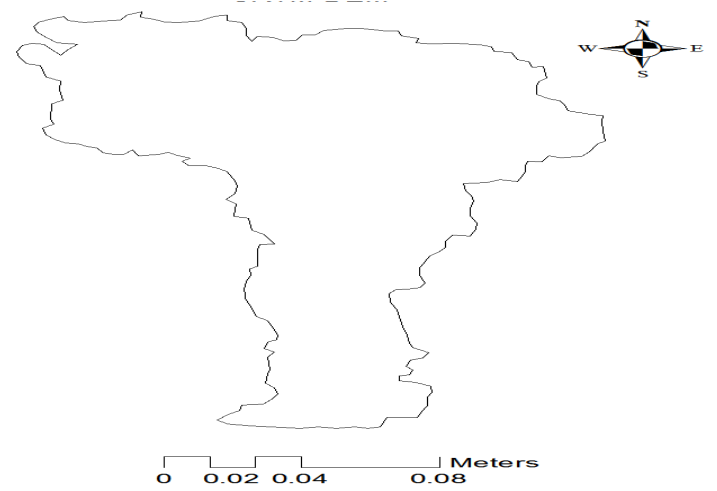

Fig. 14. Map of Garra sub-watershed, SRTM DEM dependent boundary.

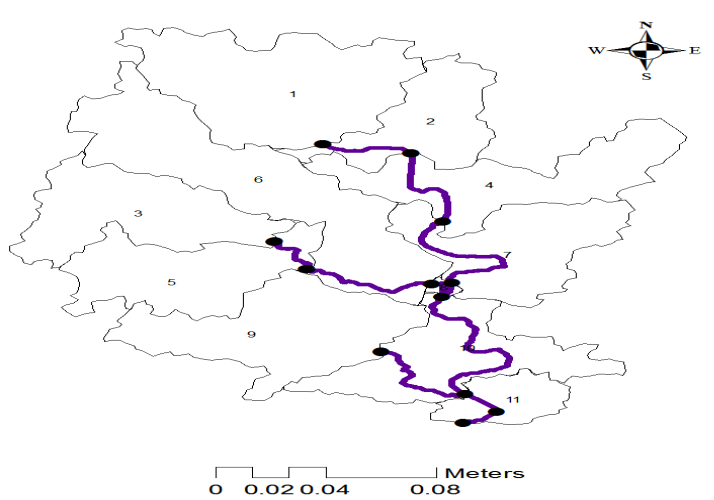

Fig. 15. Map of Micro sub-watersheds in the Garra subwatershed, CARTOSAT-1DEM dependent boundary. 


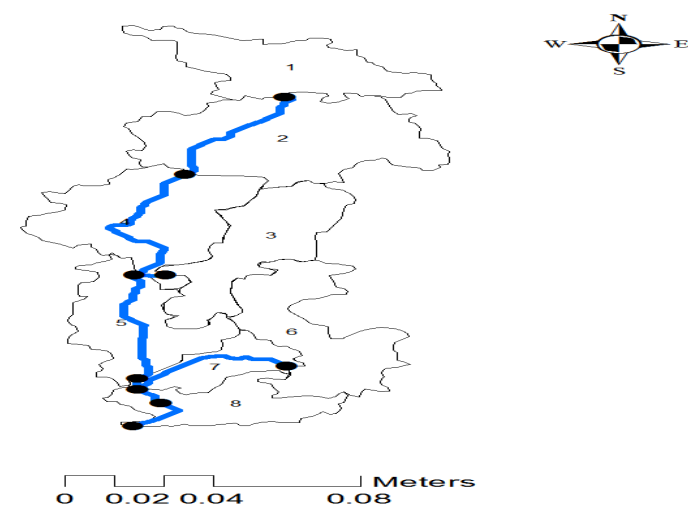

Fig. 16. Map of Micro sub-watersheds in the Garra sub-watershed, ASTER DEM dependent boundary.

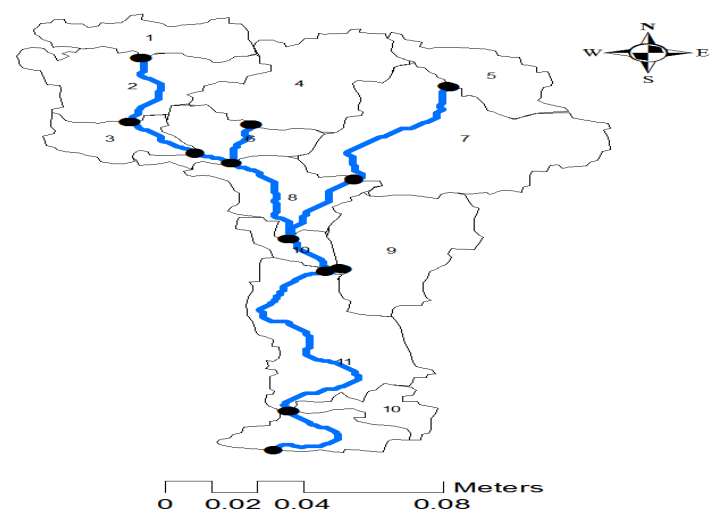

Fig. 17. Map of Micro sub-watersheds in the Garra sub-watershed, SRTM DEM dependent boundary.

edcsgs9.cr.usgs.gov/pub/data/srtm/A.Norte/). Downloaded SRTM data contains many voids (gaps) occurring at various positions with the digital value (-140) (Fig. 3). The voids were filled by using the ENVI $_{\text {(ITT Visual Information Solutions) }}+$ IDL 4.5, with the bad values (-140) replaced (Bhang and Schwartz, 2008). Comparison of all the elevation values was done with the elevation values of DEM from the digitized contour lines.

Dataset from ASTER: Here, an ASTER DEM of a resolution of $30 \mathrm{~m}$ was taken on October 02, 2009 (http://www.gdem.aster.ersdac.or.jp. Freely available) covering the entire Shahjahanpur district of Uttar Pradesh, India was acquired.

Generation of DEM from CARTOSAT-1 data: Transformation between the image space and object space is represented by application of Rational Functions (RFs) in photogrammetry and remote sensing whenever the rigorous model is made unavailable intentionally or unintentionally. With the release of high resolution images, this is gaining more attention among the users with only RF coefficients (Egels and Kasser, 1998; DeVencia et al., 2007; Gianinetto, 2008; Gianinetto and Fassi, 2008). Eleven GCPs were used for evaluating the CARTOSAT-1 data of Shahjahanpur to refine the orbital parameters of Fore and Aft scenes. Geodetic Single Frequency GPS was used in Relative mode to assemble the GCPs of this area. Fig. 4 shows that eight ground points were used as GCPs and three points on the ground were used as Tie points while generating the stereo model.

Triangulation was used to refine the exterior orientation parameters by the eight GCPs. As shown in fig. 5, DEMs were generated after triangulation. The known points on the ground were used as GCPs along with tie points to evaluate the DEM generated using CARTOSAT-1 stereo data of Shahjahanpur area (Gianinetto, 2008; Gianinetto and Fassi, 2008; Krishna et al., 2008).

DEM from SRTM: A digital elevation model (DEM) (Table 1) used for this study area (Fig. 6) with resolution of 90 meter of SRTM available on http:// srtm.csi.cgiar.org/

DEM from ASTER: A digital elevation model (DEM) used for Garra sub-watershed (Fig. 7) with resolution of 30 meter of ASTER available on http:// www.gdem.aster.ersdac.or.jp/

Software used for analysis: The main software used for compiling and analyzing the data, is ArgGIS 9.2 (ESRI) and SWAT. ArgGIS-9.2 has a very good GIS operation capability and SWAT model is specially built for ArgGIS 9.2. With the added advantage of SWAT extension, ArgGIS 9.2 is well suited for the present study.

The SWAT model was developed and maintained by the U.S. Department of Agriculture (USDA) Agricultural Research Service or ARS (Arnold et al., 1998), which incorporates features of several ARS models. Moreover, it is a direct outgrowth of the simulator for Water Resources in Rural Basins (SWRRB) model and Routing Outputs to Outlet (ROTO) model (Arnold et al., 1995). Additionally, there are some specific models viz. Chemicals, Runoff, and Erosion from Agricul-

Table 1: Metadata of Satellite data set for study area.

\begin{tabular}{|c|c|c|c|c|c|}
\hline Data & $\begin{array}{c}\text { Original } \\
\text { projection }\end{array}$ & $\begin{array}{l}\text { Original } \\
\text { resolution }\end{array}$ & $\begin{array}{l}\text { Satellite/ } \\
\text { Source }\end{array}$ & $\begin{array}{c}\text { Description of } \\
\text { original format }\end{array}$ & Purpose \\
\hline SRTM DEM & Lat/Long & $90 \times 90 \mathrm{~m}$ & $\begin{array}{c}\text { NASA } \\
\text { Shuttle } \\
\text { Mission }\end{array}$ & $\begin{array}{c}\text { One tiles covering } \\
\text { study area }\end{array}$ & $\begin{array}{l}\text { Sub-watershed and Micro- } \\
\text { sub watershed delineation }\end{array}$ \\
\hline ASTER DEM & Lat/Long & $30 \times 30 \mathrm{~m}$ & $\begin{array}{c}\text { NASA } \\
\text { Terra } \\
\text { Satellite }\end{array}$ & $\begin{array}{c}\text { One tiles covering } \\
\text { study area }\end{array}$ & $\begin{array}{l}\text { Sub-watershed and Micro } \\
\text { sub- watershed delineation }\end{array}$ \\
\hline $\begin{array}{l}\text { CARTOSAT- } \\
1 \text { DEM }\end{array}$ & Lat/Long & $2.6 \times 2.6 \mathrm{~m}$ & $\begin{array}{c}\text { ISRO } \\
\text { Satellite }\end{array}$ & Row and Path & $\begin{array}{l}\text { Sub-Watershed and Micro } \\
\text {-sub watershed delineation }\end{array}$ \\
\hline
\end{tabular}


Table 2. Responses of input DEM resolutions on SWAT model predictions at varying DEM resolutions on delineated sub-watershed properties.

\begin{tabular}{lcccc}
\hline DEM resolution & $\begin{array}{c}\text { SW area } \\
\left(\mathbf{K M}^{2}\right)\end{array}$ & $\begin{array}{c}\text { Number of } \\
\text { MSW }\end{array}$ & SW length $(\mathbf{K m})$ & $\begin{array}{c}\text { Elevation ranges for } \\
\text { MSW }\end{array}$ \\
\hline $90 \times 90 \mathrm{~m}$ & 0.0218 & 11 & 0.947 & $157 \mathrm{~m}-149 \mathrm{~m}$ \\
$30 \times 30 \mathrm{~m}$ & 0.0175 & 8 & 0.933 & $134 \mathrm{~m}-145 \mathrm{~m}$ \\
$2.6 \times 2.6 \mathrm{~m}$ & 0.0438 & 11 & 1.347 & $112.67 \mathrm{~m}-98.42 \mathrm{~m}$ \\
\hline
\end{tabular}

MSW: Micro sub-Watershed and SW: sub-Watershed.

Table 3. Responses of input DEM resolutions on SWAT model predictions at varying DEM resolutions on delineated micro sub-watershed properties.

\begin{tabular}{|c|c|c|c|c|c|c|c|c|c|}
\hline & \multicolumn{3}{|c|}{ CARTOSAT-1 } & \multicolumn{3}{|c|}{ SRTM } & \multicolumn{3}{|c|}{ ASTER } \\
\hline $\begin{array}{c}\mathbf{S} \\
\mathbf{M} \\
\mathbf{W} \\
\text { No }\end{array}$ & $\begin{array}{c}\text { Area of } \\
\text { MSW } \\
\left(\mathbf{k m}^{2}\right)\end{array}$ & $\begin{array}{l}\text { MSW } \\
\text { Length } \\
(\mathbf{k m})\end{array}$ & $\begin{array}{c}\text { Elevation } \\
\text { Max } \\
\text { Ranges } \\
\text { for MSW } \\
\text { (m) }\end{array}$ & $\begin{array}{c}\text { Area of } \\
\text { MSW } \\
\left(\mathbf{k m}^{2}\right)\end{array}$ & $\begin{array}{c}\text { MSW } \\
\text { Length } \\
(\mathbf{k m})\end{array}$ & $\begin{array}{c}\text { Elevation } \\
\text { Max } \\
\text { Ranges } \\
\text { for MSW } \\
\text { (m) }\end{array}$ & $\begin{array}{c}\text { Area of } \\
\text { MSW } \\
\left(\mathbf{k m}^{2}\right)\end{array}$ & $\begin{array}{c}\text { MSW } \\
\text { Length } \\
(\mathbf{k m})\end{array}$ & $\begin{array}{c}\text { Eleva- } \\
\text { tion Max } \\
\text { Ranges } \\
\text { for } \\
\text { MSW } \\
\text { (m) }\end{array}$ \\
\hline 1 & 0.006464 & 0.420059 & 112.67 & 0.001148 & 0.184834 & 154 & 0.002097 & 0.279184 & 140 \\
\hline 2 & 0.002943 & 0.337659 & 107.69 & 0.002055 & 0.246046 & 149 & 0.003727 & 0.316407 & 145 \\
\hline 3 & 0.004263 & 0.392487 & 112.19 & 0.000838 & 0.148365 & 150 & 0.002188 & 0.300011 & 137 \\
\hline 4 & 0.004392 & 0.4705 & 111.92 & 0.002305 & 0.248039 & 158 & 0.002879 & 0.291767 & 141 \\
\hline 5 & 0.003917 & 0.403708 & 108.33 & 0.001182 & 0.185596 & 150 & 0.00201 & 0.288199 & 138 \\
\hline 6 & 0.007198 & 0.589794 & 108.28 & 0.001094 & 0.1903 & 150 & 0.002311 & 0.348273 & 135 \\
\hline 7 & 0.003937 & 0.36445 & 101.44 & 0.004311 & 0.328223 & 157 & 0.000892 & 0.162966 & 134 \\
\hline 8 & 0.000111 & 0.044572 & 98.42 & 0.00141 & 0.199125 & 140 & 0.001355 & 0.235349 & 134 \\
\hline 9 & 0.005122 & 0.414725 & 102.91 & 0.002382 & 0.228652 & 151 & Nil & Nil & Nill \\
\hline 10 & 0.004087 & 0.420175 & 100.36 & 0.001091 & 0.283784 & 150 & Nil & Nil & Nill \\
\hline 11 & 0.001354 & 0.171661 & 98.72 & 0.003903 & 0.438868 & 152 & Nil & Nil & Nill \\
\hline
\end{tabular}

MSW: Micro sub-Watershed.

tural Management Systems (CREAMS) model that contributed significantly to the development of SWAT (Knisel, 1980).

Basics of automated sub-watershed delineation from different sources DEMs: Sub-watershed boundaries were derived from the DEMs using SWAT model automated procedures with the Sub-watershed Delineator. $2.6 \mathrm{~m}, 30 \mathrm{~m}$ and $90 \mathrm{~m}$ resolution DEM data (Table 1) was used to extract the boundary of sub-watershed and the process was composed of main three steps.

The first step is to fill the depression (Sink) in DEM (Fig. 8). Depression refers to a cell whose elevation value was lower than that of any of its neighbor cells. This phenomenon occurs when the breadth of valley is less than the grid size and the low value of valley decreases the average value of the cell. Since depression usually occurs in upper stream, it is necessary to fill the depression before determining the flow direction. The second step is to determine the direction of flow from every cell in the grid. This function takes a grid surface as input and generates a grid output that shows the direction of flow out of each cell (Figs. 9 and 10). There are eight valid output directions, relating to the eight adjacent cells into which flow could travel. Former elevation values of each cell is substituted by one number among $1,2,4$, $8,16,32,64,128$ for potential flow direction of east, southeast, south, southwest, west, northwest, north, and northeast. Thus a new digital grid with flow direction is recorded, which is called as flow direction grid. The last step is 'flow accumulation', which calculated accumulating flow as the accumulated weight of all cells flowing into each down slope cell in the output grid (Fig. 10) (Lindsay, 2008) If no value was assigned to the grid, a value of one was applied to each cell, and the value of cells in the output grid would be the number of cells that flowed into each cell.

All the commands were completed in SWAT environment and the ensuing boundary map was obtained as fig. 11.

\section{RESULTS AND DISCUSSION}

The sub-watershed (Figs. 12 to 14) and micro sub-watersheds (Figs.15 to 17) boundary was computed with an automated procedure using digital data (DEM) and represents an estimate of the sub-watershed and micro sub-watersheds boundary determined with the best available Digital Elevation Model (DEM)-analysis SWAT model.

The effect of input DEM data resolution on delineated sub-watershed area, number of micro sub-watersheds 


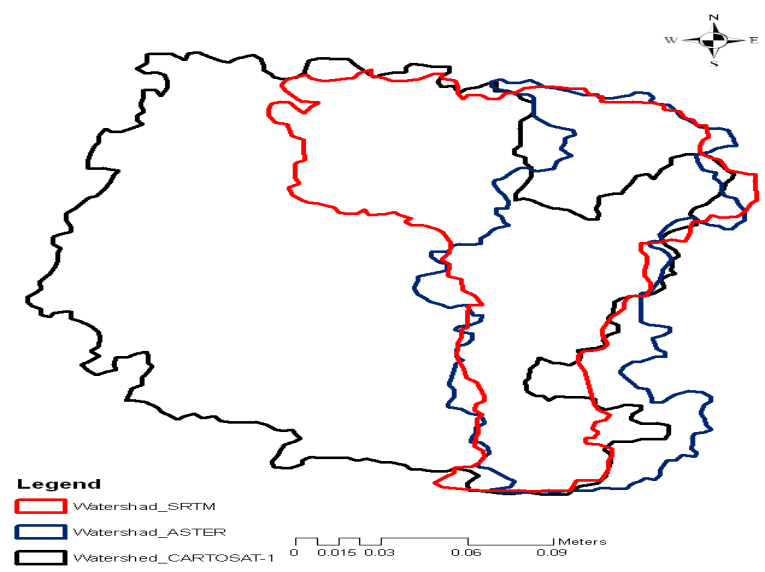

Fig. 18. CARTOSAT-1, ASTER and SRTM DEMs dependent sub-watershed boundaries comparison.
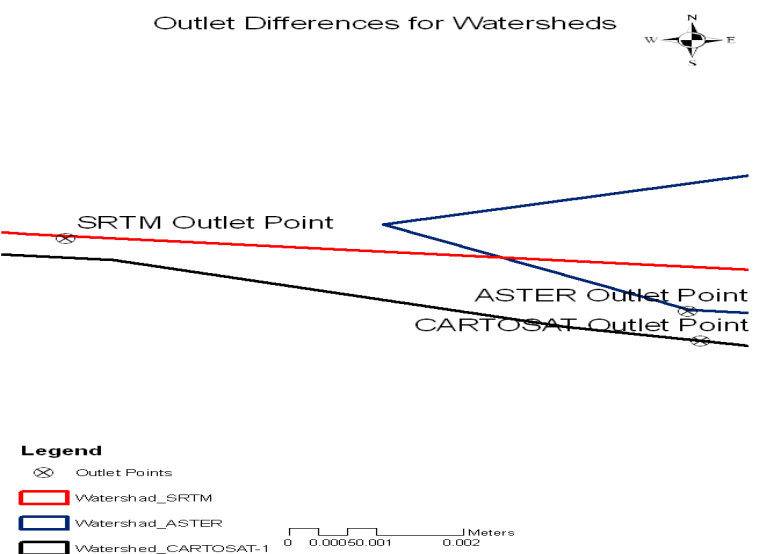

Fig. 19. CARTOSAT-1, ASTER and SRTM DEMs dependent sub-watershed outlet comparison.

is shown in table 2. If we consider the $2.6 \times 2.6 \mathrm{~m}$ DEM data to give the best estimate of the sub-watershed properties, table 2 shows that all other DEM resolutions resulted in different sub-watershed delineation, sub-watershed area and number of subwatershads (Figs. 14 to 17, Table 3). The effect was most significant for $90 \times 90 \mathrm{~m}$ and $30 \times 30 \mathrm{~m}$ resolution, where the area of sub-watershed estimated was $49.77 \%$ and $39.95 \%$, respectively with respect to CAROSAT-1 derived sub-watershed area. The SWAT delineated sub-watershed boundary, micro subwatersheds and major stream network for three DEM resolutions are shown in fig. 14 to 17 . The subwatershed and major stream network representation became increasingly less accurate with decrease in DEM resolution.

Visually, there are much differences between the CARTOSAT-1 DEM based boundaries delineated and the SRTM DEM and ASTER DEM based boundaries (Fig. 18), while the ASTER DEM and SRTM DEM based boundary are some close to each other at right hand side only because right hand side stream is clearly shows in each DEMs. The area of the subwatershed delineated from CARTOSAT- 1 is 0.0438 $\mathrm{Km}^{2}$, while the SRTM-based sub-watershed area is
Table 4. Effect of different resolution DEM on SWAT model for predictions of outlet (at different elevation) of sub-watershed .

\begin{tabular}{lc}
\hline Elevation of outlet from different DEM & $\begin{array}{c}\text { Elevation } \\
(\mathbf{m})\end{array}$ \\
\hline $\begin{array}{l}\text { Elevation of outlet point of sub-watershed } \\
\text { from SRTM-DEM }\end{array}$ & 142 \\
$\begin{array}{l}\text { Elevation of outlet point of sub-watershed } \\
\text { from ASTER-DEM }\end{array}$ & 131 \\
$\begin{array}{l}\text { Elevation of outlet point of sub-watershed } \\
\text { from CARTOSAT-1-DEM }\end{array}$ & 94.72 \\
\hline
\end{tabular}

$0.0218 \mathrm{Km}^{2}$ (49.77169\% of CARTOSAT-1 based sub -watershed area), and the ASTER-based sub-watershed area is $0.0175 \mathrm{Km}^{2}$ (39.95434\% of CARTOSAT-1 based sub-watershed area). The numbers of micro sub-watersheds were also affected by the DEM resolution, possibly due to differences in subwatershed and stream network delineation by the SWAT model. Table 3 shows that number of micro sub-watersheds within the sub-watershed increased for $2.6 \times 2.6 \mathrm{~m}$ and $90 \times 90 \mathrm{~m}$ decreased for $30 \times 30 \mathrm{~m}$ DEM resolution because ASTER DEMs could be generated without GCPs so Microwave based SRTM data provide better alternatives for associated topographical applications because usually ASTER DEM is based on several images, named as stacks (Hasan et al., 2011). In this analysis we also found that outlet point of Garra watershed have put different elevation for Different DEMs, and minimum, maximum outlet elevation value is $94.72 \mathrm{~m}, 142 \mathrm{~m}$ found from CARTOSAT-1, SRTM DEM respectively (Table 3), but distances of outlet point from SRTM DEM based boundaries to CARTOSAT-1 based boundaries is 7.63 $\mathrm{m}$ while $0.65 \mathrm{~m}$ (Fig. 19, Table 4) distances found from CARTOSAT-1 to ASTER because outlet point of sub-watershed always will be effective due to sum of total input of sub-watershed finally out come from this point so this point can be easily dedicated from any resolution data of DEM.

\section{Conclusion}

The results of our effort indicated evaluatation of sub-watershed delineation on DEMs of different source. The accuracy of the sub-watershed delineation is highly dependent on the accuracy and good quality of the Digital Elevation Model available. ASTER data have several advantages, including low cost, high spatial resolution, good correlation over vegetated areas. Its disadvantages include mainly the potential masking by clouds and ASTER DEMs generated without GCPs. There have been other topographic datasets however, elevation models produced from SRTM data will be the highest resolution datasets ever produced for Earth's land surface. This clearly gives SRTM and edge over the existing global elevation data due to the increase in spatial resolution and vertical accuracy. SRTM DEMs, when fused with other types of satellite derived data such as ASTER, leads to improved resolution results but not much improve to 
topographic results. The input DEM data resolution affected SWAT model results as the total area of delineated sub-watershed, predicted stream network and sub-watershed were affected by it. It was found that the choice of input DEM data resolution for the SWAT model depends on the output of interest. Efforts must be applied to collect and input DEM data at finer resolutions to minimize the uncertainties in the model predictions as the use of the SWAT model in making sub-watershed response predictions are expected to increase in future. This work is only the first step in providing a Geographic Information System (GIS) framework for primary level study of Garrah Sub-watershed. This study demonstrates that developing an accurate sub-watershed analysis for various uses with a minimum amount of time, effort and cost can certainly be achieved by using remotely sensed data and available software.

\section{REFERENCES}

Arnold, J.G., Williams, J.R. and Maidment, D. R. (1995). Continuous-time Water and Sediment Routing Model for Large Basins. Journal of Hydraulic Engineering, 121:171-183.

Arnold, J.G., Williams, J.R. and Maidment, D. R. (1998). Large area hydrologic modeling and assessment part I: model development. $J$. of the American Water Resources Association, 34:73-89.

Baker, M.E. and Weller, D. E. (2006). Comparison of automated watershed delineations: effects on land cover areas, percentages and relationships to nutrient discharge. Photogrammetric Engineering and Remote Sensing, 72:159-168.

Bhang, K. J. and Schwartz, F.W. (2008). Limitations in the Hydrologic Applications of C-Band SRTM DEMs in Low-Relief Settings. IEEE Geoscience and Remote Sensing Letters, 5:497-501.

DeVencia, K., Walker, S. and Zhang, B. (2007). New approaches to generating and processing high resolution elevation data with imagery. 'Proceedings of Photogrammetric week 2007, Stuttgart, Germany', 297 308.

Rawat, K.S., Mishra, A.K. and Tripathi, V.K. (2013). Hydro-morphometrical analyses of sub-himalyan region in relation to small hydro-electric power. Arabian Journal of Geosciences. 6(8): 2889-2899.

Egels, Y. and Kasser, M. (1998). Monuments historiques levers photogrammétriques. Digital Photogrammetry, Revue Géomètre, 3:41-43.

Estrada, R.D. and Posner, J. (2001). The Watershed as an organizing principle for research and development: An evaluation of experience in the Andean Ecoregion. Mountain Research and Development, 21:123-127.

Gianinetto, M. and Fassi, F. (2008). Alidation of cartosat-1 dtm generation for the salon de provence test site. International Society of Photogrmatry and Remote Sensing, 37:1374.

Gianinetto, M. (2008). Automatic digital terrain model generation using cartosat-1 stereo images. Sensor Review, 28:299-310.

Grohmann, G., Kroenung, G. and Strebeck, J. (2006). filling SRTM voids: The delta surface fill method. Photogrammetric Engineering and Remote Sensing, 72: 213-216.

Hasan, A., Pilesjö, P. and Persson, A. (2011). The use of LiDAR as a data source for digital elevation models DEM resolution versus accuracy and estimated slope, drainage area and wetness in northern peatlands. Hydrology and Earth System Sciences, discussion paper

Hall, O., Falorni, G. and Bras, R. L. (2005). Characterization and quantification of data voids in the shuttle Radar topography mission data, IEEE Geoscience and Remote Sensing Letter, 2:177-181.

Jenson, S. K., Domingue, J. O. (1988). Extracting topographic structure from digital elevation data for geographic information system analysis. Photogrammetric Engineering and Remote Sensing, 54:593-1600.

Krishna, M.Y.V.N., Srinivasa, R.S., Prakasa, R.R.S. and Jayaraman, V. (2008). Analysis of dem generated using catosat-1 stereo data over Mausanne Les Alpiles. International Society of Photogrmatry and Remote Sensing, 37:1343-1348.

Knisel, W.G. (1980). USDA - Agricultural research service, Washington DC. Cons. Res Rpt 26:643.

Lindsay, J. B., Rothwell, J. J., Helen, D. (2008). Mapping outlet points used for watershed delineation onto DEMderived stream networks. Water Resources Research, 44:12-20.

Luedeling, E., Siebertb, S. and Buerkerta, A. (2007). Filling the voids in the SRTM elevation model-A TIN-based delta surface approach. International Society of Photogrmatry and Remote Sensing, 62:283-294.

Maidment, D. (1999). Environmental systems research institute, available online at http:/ Icampus.esri.coml courses/hydrolgy IwatShdhy.

Marks, D., Dozier, J. and Frew, J. (1984). Automated basin delineation from digital elevation data. Geo-Processing, 2:299-311.

Rabus, B., Eineder, M. and Bamler, R. (2003). The shuttle radar topography mission-a new class of digital elevation models acquired by spaceborne radar. Photogrammetry and Remote Sensing, 57:241-262. 